\title{
Evaluation in public political speech of German Chancellor Helmut Schmidt
}

\author{
Yakovleva A.S. \\ Tyumen industrial University \\ Tyumen, Russia \\ jakovlewa@mail.ru
}

\author{
Pogorelova S.D. \\ Tyumen industrial University \\ Tyumen, Russia \\ pogorelovasd1@tyuiu.ru
}

\begin{abstract}
The paper discusses evaluation in public political speech (as illustrated by the political speech of German Chancellor Helmut Schmidt). Various approaches to the study of evaluation, the nature and typology of evaluation are considered; the study of an evaluative situation involving obligatory and optional components is conducted: a subject of evaluation, an object of evaluation, content of evaluation, a reason of evaluation and a recipient - a component that is vital from the viewpoint of pragmatics. The rules and principles of public political speech composition and the components of speech composition considered in the science of eloquence - rhetoric - are analyzed (N.A. Bezmenova, Yu. V. Rozhdestvensky, E.N. Zaretskaya, I.A. Sternin, et al.). Public political speech is sequentially structured with a certain sequence of the speech composition components. Each component of the speech structure consists of the composition-speech forms: narration, description and reasoning (argumentation) (O.A. Nechaeva, N.V. Bessmertnaya, M.P. Brandes, S. K. Shendels, K. A. Andreeva). Argumentation is a composition-speech form of the public political speech structure, i.e. a set of arguments, a way of producing them to justify a certain statement. A linguistic analysis of the principal means of expressing the attitudinal meaning in one of the most striking speeches of German Chancellor Helmut Schmidt is carried out based on the developed model.
\end{abstract}

Keywords-evaluation, evaluative situation, components of evaluative situation, structure of political speech

\section{INTRODUCTION}

Evaluation implemented in a certain evaluative situation is considered in the context of one of the public political speeches of German Chancellor Helmut Schmidt through word-formative, lexical and syntactic linguistic means.

Different approaches to the study of evaluation exist in modern linguistics (A.A. Ivin, N.D. Arutyunova, E.M. Volf, V.N. Telia, T.V. Markelova, A. Vezhbitskaya, T.I. Vendina, Yu.S. Stepanov, et al.).

In this study, evaluation is defined as the ratio of the native speakers to the object due to recognition or non-recognition of its value in terms of the equivalence of its qualities to certain value criteria.

In the process of communication, a person expresses his attitude to certain realities; a certain evaluative situation involving a number of obligatory and optional components arises. In public political speech, in the authors' opinion, the evaluative situation can be analyzed through five components: a subject of evaluation, an object of evaluation, content of evaluation, a reason of evaluation and a recipient - a component that is vital from the point of view of pragmatics.

Evaluation expressed in the evaluative situation performs a number of functions in the speech context; primarily it serves to express the speaker's attitude to reality with his desire to attract the attention of the recipient and influence it.

Evaluation occurring in the public political speeches of Helmut Schmidt is of interest as the most important aspect of the language personality and as a living model of innovation in language and speech activity.

The existing views on evaluation, nature, typology and a structure of the evaluative situation, the association of evaluation with other categories and its functional significance in the context have been analyzed in detail in the course of the study.

The rules and principles of public political speech composition, the components of speech composition considered in the science of eloquence - rhetoric - are analyzed (N.A. Bezmenova, Yu. V. Rozhdestvensky, E.N. Zaretskaya, I.A. Sternin, et al.). Rhetoric deals with the problems of constructing texts and implementing speech effects (N.A. Bezmenova, Yu. V. Rozhdestvensky, E.N. Zaretskaya, I.A. Sternin, et al.).

Public political speech is sequentially structured with a certain sequence of the speech composition components. Several classifications of speech composition given in the paper were proposed by the well-known authors (P.L. Soper, E.N. Shiryaev, N.N. Kokhtev, H. Lemmerman, E.N. Zaretskaya, A.N. Vasilieva, M. R. Lvov et.al).

Each component of the speech structure consists of the composition-speech forms: narration, description and reasoning (argumentation) (O.A. Nechaeva, N.V. Bessmertnaya, M.P. Brandes, S. K. Shendels, K. A. Andreeva). Argumentation is a composition-speech form of the public political speech structure, i.e. a set of arguments, a way of producing them to justify a certain statement.

\section{MAIN PART}

Various classifications of argumentation types and methods have been considered in the course of the study (A.N. 
Baranov, N.N. Kokhtev, A.A. Ivin, G.I. Ruzavin, I.A. Sternin, L.G. Babenko). A linguistic analysis of the principal means of expressing the attitudinal meaning in one of the most striking speeches of German Chancellor Helmut Schmidt has been carried out based on the model developed by one of the authors in her thesis research [1]

1. Every public political speech is devoted to a specific topic targeting a concrete person, an event, a phenomenon, a state of affairs, an object of reality, a situation, i.e., "some valuable part of the real world" [2]. Thus, the first step of this analysis is to present the communicative situation, select the object of speech and the objective pursued by the speaker in the given public political speech.

2. When presenting the communicative situation, the speaker expresses his attitude to the object of speech, i.e. he gives a positive or negative evaluation; having set an objective to convince the recipient in his rightness, he makes him believe in his words, agree and accept his point of view. However, in the public political speech, it is sometimes difficult to single out this evaluation. Therefore, it is advisable to consider the structure of the political speech and determine the components of speech composition which make it possible to identify the evaluative situations and their components. Thus, the second step of this analysis is to consider the political speech composition and encode the components of speech composition. In the authors' opinion, the most detailed composition of a political speech is given in the work of E.N. Zaretskaya. After E.N. Zaretskaya, let us distinguish the following components of the public political speech composition:

\section{Address.}

\section{Subject matter.}

III. Main body consisting of composition-speech forms: narration, description and argumentation.

\section{Conclusion (appeal, prospects).}

3. When analyzing the composition of public political speech, the authors found out that each component of the speech composition includes a certain evaluative situation (in some cases, a number of evaluative situations). Each evaluative situation, in its turn, reflects the positive or negative attitude of the speaker to a particular object of speech, and in combination, they reveal the content of the general object of speech, i.e. the object of evaluation, its positive or negative sides that served as the basis for the particular evaluation. In here, it should be noted that the content of evaluation is primarily determined by 2 factors - the subject of evaluation and the reason of evaluation, the immediate constituents of the evaluative situation. Therefore, the third step of the authors' analysis is to identify the evaluative situations and to analyze their main components - a subject of evaluation, an object of evaluation, content of evaluation, a reason of evaluation and a recipient.

4. Thus, evaluation encoded in the structure of political speech is realized in evaluative situations and expressed in the word-formative, lexical and syntactic levels of the language. The final step is the analysis of the main linguistic means of expressing the attitudinal meaning. In this paper, attention is being paid to word-formative, lexical and syntactic means.

In any public political speech, one can single out a whole complex of expressive syntactic means that serve to express and accentuate the attitudinal meaning: a rhetorical question; lexical and grammatical repetition; a metaphorical phrase and a sentence; antithesis; a sentence containing isolated groups; an expressive-stylistic word position; an imperative sentence; parenthetical enclosure, etc. The special syntagmatic segmentation of the speech serves as the general structural basis for these constructions. "The expressive constructions, being highly intonated and increasingly logical, expand their own expressive-stylistic possibilities in comparison with the ordinary syntactic constructions" [2].

The means of expressive syntax and their functions are mentioned by a number of well-known linguists (V.A. Beloshapkova 1977; G.N. Akimova 1981; M.N. Kozhina 1983; O.V. Alexandrova 1984; A.P. Skovorodnikov 1984; O.L. Kostrova 2004, et.al), as well as by the linguists involved in the study of the political language (Yu. N. Karaulov 1987; N.A. Bezmenova 1991; A.N. Baranov 1993; V. I. Shakhovsky 1998; A.P. Chudinov 2000). Studies on the particular characteristics of these units of language in public political speeches are highly incomplete and unilateral. This is due to recognition of these syntactic means in public political speeches as "an individual approach that helps to establish a verbal contact, but not as an essential sign of the speaker's speech arising from the targets of this type of communication and having the status of a style-forming system sign" [3].

Thus, the means of expressive syntax in political speech function as a unity, a system. They not only deliver information to the recipient, stirring up his cognitive interest, but also make him think about the evaluation of what is happening, focus the audience on some important points. The recipient completely realizes the speaker's evaluation of a particular event, phenomenon, object of reality and their mutual understanding.

Metaphor is one of the most common syntactic means of expressing evaluation in public political speech (metaphorical phrases and metaphorical sentences). After M.N. Kozhina, a metaphor is "a word or a turn of speech used in a figurative meaning to define an object or phenomenon on the basis of an analogy" [4]. The analysis has revealed that the metaphor is actively used in public political speeches, since it aims at "influencing not only the minds, but also the feelings of recipients, and its propaganda-agitation function is effectively realized in the expressive speech" [4]. I.M. Kobozeva, when considering the functional plan of the metaphor in political texts, underlines that it performs an "interactive function of smoothing out the most dangerous political statements touching on controversial political problems, minimizing the speaker's responsibility for the possible literal interpretation of his opinion by the addressee" [5] .

The analysis of public political speeches made it possible to distinguish, alongside with lexical repetition, a number of constructions that perform two important functions in the composition of political speech. On the one hand, they are the means of "accentuating evaluative meanings" [6] with a focus 
The appeal to the audience is also observed during the speaker's speech, for example: «Ich sage vor allem den jungen Menschen...»; « Ich sage aber in großem Ernst»; «Zum Schluss meine Damen und Herren!».

When considering the language expression plan, the authors have found out that it can be expressed in the form of the pronoun «Sie», a noun with a possessive pronoun «-meine Damen und Herren-». The speaker constantly appeals to the audience, urging the recipients not to remain indifferent and passive, affiliating himself with the audience, for example: «Ich weiss, wie schwer es Älteren oft ist...»; « haben wir...»; «stehen wir auch....».

To convince the audience, Helmut Schmidt passes on to the main body of his political speech. The main body reveals the object of his speech, i.e. the object of evaluation - attempt, terror and violence.

The main body of his speech includes such compositionspeech forms as narration, description (facts, objects of reality, people's behavior and actions) and argumentation, thus the speaker tries to make the audience believe in his words.

The last component presents a conclusion in which Helmut Schmidt repeatedly appeals to the recipients to be able to take responsibility, not to remain indifferent.

Let us structure the analyzed public political speech in the following way:

Scheme 1. Public political speech composition

\section{Address}

$\downarrow$

\section{Subject matter}

\section{$\downarrow$}

Terror and violence

III. Main body:

Topic:

Terror and violence

$\downarrow$

\section{Conclusion (appeal)}

The scheme presents the components and the composition of political speech devoted to a big topic, namely the struggle against terror and violence.

The analysis of the composition has made it possible to distinguish a number of evaluative situations in the components of speech composition. The subjects, phenomena, the state of affairs and processes are the objects of these situations. Let us pass on to the next step of analysis and point out the evaluative situations and their components. 8 evaluative situations have been singled out in the analyzed speech. The evaluative situation includes 5 components: subject of evaluation - object of evaluation - content of evaluation - reason of evaluation - recipient. If one considers the components of the evaluative situation, it will make it possible to determine the basis for positive or negative 
evaluation of the speaker of a particular object, phenomenon, action, fact, etc.

The speaker is the subject of evaluation on the whole of evaluative situations. In most evaluative situations, the subject of evaluation is expressed implicitly. For example, «Es gibt kein politisches Prinzip, mit dem der Rückfallbvon der Menschlichkeit in die Barbarei sittlich gerechtfertigt könnte».

The object of evaluation in the analyzed political speech of Helmut Schmidt is expressed by the noun. The analysis has made it possible to distinguish the following semantic subgroups of the noun: nouns denoting an action or feature of the object (persons, phenomena): die Begründung, der Umgang, die Erfahrungen, die Maßnahmen, das Prinzip, etc; nouns denoting objects or phenomena: die Schutzpflicht, die Geschichte, die Macht, die Verstrickung, die Wahrnehmung, das Grundgesetz, etc.

When considering the evaluative situations in this public political speech, one can conclude that evaluation has a positive content (pride, confidence, protection) in 4 out of 8 evaluative situations, 4 - negative content (disappointment, disapproval, irony, discontent). The content of the given evaluative situations forms an idea of the positive and negative sides of the object of evaluation - violence and terror.

Such component of the evaluative situation as the reason for evaluation in public political speeches of Helmut Schmidt has showed that it is represented in the structure of speech as one of the composition-speech forms of the public political speech - argumentation, its types and techniques: support, i.e. factual reasoning, explanation, confirmation and conviction.

Helmut Schmidt uses different types and ways of argumentation for reasoning, for example, he quite often refers to the obvious facts: «Die ganze Welt erfährt in diesen Jahren in vielen Ländern das Wiederaufleben zerstörerischer Gewalt, von der die Venschheit glaubte, dass sie durch geschichtliche Erfahrung und durch menschliche Moral überwunden sei.... ».

The reference to past experience is: «Ich sage aber in grossem Ernst, dass es unheilvolle Erfahrungen gibt, von denen man sich schützen muss, die man selber nicht machen wollen darf, wo eigene Einsicht und Verantwortung gebieten, zuzuhören und zu bedenken und zu lernen».

Each evaluative statement in the public political speech of Helmut Schmidt is realized by linguistic means. At the next step of analysis, the main linguistic possibilities of expressing the attitudinal meaning have been considered: word-formative, lexical and syntactic levels of language which are closely interrelated. When evaluating this or that object of speech (subject, phenomenon of reality, event), the speaker uses them simultaneously.

- Various suffixes and prefixes with negative or positive evaluation semes have been analyzed: ver-, un-, ent-, -d, -isch, -lich, -ig:

- ver- : verpflichten, verbieten, Verstrickung, Versäumnis;

- un-: unvermeidlich, unausweichlich; unheilvoll;
- $\quad$-d: umfassend, entscheidend;

- -lich: menschlich,sittlich,geschichtlich;

- $\quad$-isch: zerstörerisch, politisch;

- $\quad$ ig:richtig, wichtig.

It is reasonable to single out 2 groups of words at the lexical level.

The first group involves words that include evaluation as an integral component, i.e. expressing it lexically. They are:

- $\quad$ adjectives (in combination with neutral nouns): zerstörerische Gewalt, humane Geschichte, vermeintliche Macht, unheilvolle Erfahrungen, existenzielle Begründung, etc.

- nouns: Versäumnis, Schuld, Faustrecht, Selbstzerstörung, Barbarei, etc.

The second group consists of neutral words acquiring the attitudinal meaning in the communicative situation. For example, «Die Artikel 1 und 2 unseres Grundgesetzes verpflichten den Staat, jedes menschliche Leben zu schützen. Diese Schutzpflicht ist umfassend».

An intensifier of the attitudinal meaning is used in the analyzed public political speech: letztlich existenzielle Begründung.

It is necessary to point out various expressive-syntactic figures used by the speaker, e.g. lexical repetition, at the syntactic level: «Die Artikel 1 und 2 unseres Grundgesetzes verpflichten den Staat, jedes menschliche Leben zu schützen. Diese Schutzpflicht ist umfassend. Das Grundgesetz begründet eine Schutzpflicht nicht nur gegenüber dem Einzelnen, sondern auch gegenüber der Gesamtheit aller Bürger. Die Wahrnehmung dieser doppelten Pflicht setze voraus....».

In order to express the attitudinal meaning, the speaker uses the metaphor: «Wer aber aus dieser humanen Geschichte heraustritt, wer an die Stelle des demokratischen Rechts das Faustrecht der Gewalt setzt, der erlebt eine Ausweglosigkeit, in der vermeintliche Macht bis in Selbstzerstörung umschlagen kann».

The speaker also uses the parenthetical enclosure to express the attitudinal meaning: «... Wer weiß, dass er so oder so, trotz allen Bemühens, mit Versäumnis und Schuld belastet sein wird....».

Expressive-stylistic word order: «Ihre, letztlich existenzielle, Begründung findet Demokratie in der Humanisierung der Politik»; «Wohl aber wird er sagen dürfen...».

Exclamatory sentence: «Diese Verpflichtung dem Ganzen gegenüber umfasst auch, den Schwachen zu helfen, Minderheiten nicht auszuschliessen und gegenüber Andersdenkenden Respekt zu bewahren!»

\section{DISCUSSION AND CONCLUSION}

Thus, based on the observations and comparative analysis made, it is possible to draw the following conclusions: 
1 Political speech includes an object of speech which is revealed in a certain structure and components of the speech composition.

2. The rationalistic and sublimated evaluations resulting in connotations in the speech context dominate in the public political speech of Helmut Schmidt.

3. The evaluative situation includes five components: the subject of evaluation, the object of evaluation, content of evaluation, the reason of evaluation and the recipient. The subject of evaluation is usually expressed implicitly. The object of evaluation is expressed by a noun. The analysis has showed that noun-objects which denote actions or features of objects are evaluated most frequently. The content of evaluation can be positive and negative. The recipient, as a component of evaluation, is identified in almost every evaluative situation. In the authors' opinion, it is a feature of the evaluative situation function in public political speech targeting the addressee.

4. The attitudinal meaning in the public political speech of Helmut Schmidt can be expressed by word-formative, lexical and syntactic means of the language.

\section{References}

[1] A.S. Jakovleva, "Evaluation in public political speeches of P.A. Stolypin and Otto von Bismarck (as illustrated by Russian and German languages)," Diss. ... PhD in Philology, Tyumen, 2006.

[2] G. N. Akimova, "Development of expressive syntax constructions in Russian,” Issues of Linguistics, №, pp.115, 1981.
[3] A. P. Chudinov, Metaphoric mosaic in modern political communication, Monograph, 2003.

[4] M. N. Kozhina, Stylistics of Russian Language, M.: 1983.

[5] I. M. Kobozeva, Issues of semantics for analysis of political metaphor, Bulletin of Moscow State University, Ser. 9, Philology, No. 6, pp. 134, 2001.

[6] V. G. Gak, "Semantic structure of the word as a component of semantic structure of the utterance," Semantic structure of the word, M.: Vysshaja shkola, 1982.

[7] O. V. Dolgova, Semantics of irregular speech (as illustrated by English language), M.: Vyssh. Shkola, 1977.

[8] G. N. Akimova, "Development of expressive syntax constructions in Russian,” Issues of Linguistics, №, pp.115, 1981.

[9] A. N. Vasil'eva, Fundamentals of speech culture, Moscow, Russkij jazyk, 1997.

[10] V. G. Gak, "Semantic structure of the word as a component of semantic structure of the utterance," Semantic structure of the word, M.: Vysshaja shkola, 1982.

[11] O. V. Dolgova, Semantics of irregular speech (as illustrated by English language), M.: Vyssh. Shkola, 1977.

[12] E. N. Zareckaja, Rhetoric: Theory and Practice of Speech Communication, M.: Delo, 1999.

[13] I. M. Kobozeva, Issues of semantics for analysis of political metaphor, Bulletin of Moscow State University, Ser. 9, Philology, №6, pp. 134. , 2001

[14] M. N. Kozhina, Stylistics of Russian Language, M.: 1983.

[15] A. P. Chudinov, Metaphoric mosaic in modern political communication. Monograph. 2003.

[16] A.S. Jakovleva, Evaluation in public political speeches of P.A. Stolypin and Otto von Bismarck (as illustrated by Russian and German languages), Diss.... PhD in Philology, Tyumen, 2006.

[17] Helmut Schmidt-Rede "Der Terrorismus hat auf Dauer keine Chance", Retriewed from http://www.berliner-zeitung.de/25361826 @2016. 